University of Nebraska - Lincoln

DigitalCommons@University of Nebraska - Lincoln

8-1986

\title{
Late Pleistocene and Holocene Paleolimnology of Two Mountain Lakes in Western Tasmania
}

J. Platt Bradbury

USGS

Follow this and additional works at: https://digitalcommons.unl.edu/usgsstaffpub

Part of the Earth Sciences Commons

Bradbury, J. Platt, "Late Pleistocene and Holocene Paleolimnology of Two Mountain Lakes in Western Tasmania" (1986). USGS Staff -- Published Research. 253.

https://digitalcommons.unl.edu/usgsstaffpub/253

This Article is brought to you for free and open access by the US Geological Survey at DigitalCommons@University of Nebraska - Lincoln. It has been accepted for inclusion in USGS Staff -- Published Research by an authorized administrator of DigitalCommons@University of Nebraska - Lincoln. 


\title{
Late Pleistocene and Holocene Paleolimnology of Two Mountain Lakes in Western Tasmania
}

\author{
J. PLATT BRADBURY \\ U.S. Geological Survey, Denver, Colorado 80225
}

PALAIOS, 1986, V. 1, p. 381-388

The analysis of diatoms from two lake-sediment cores from southwestern Tasmania that span the Pleistocene-Holocene boundary provides insight about paleolimnological and paleoclimatic change in this region. Both Lake Vera (550 m elevation), in west-central Tasmania, and Eagle Tarn (1,033 m elevation), in south-central Tasmania, have lacustrine records that begin about 12,000 years ago. Despite significant differences in location, elevation, and geologic terrane, both lakes have had similar, as well as synchronous, limnological histories. Each appears to have been larger and more alkaline 12,000 years ago than at present, and both became shallower through time. Fossil diatom assemblages about 11,500 years old indicate shallow-water enviromments that fluctuated in $\mathrm{pH}$ between acidic and alkaline, and between dilute and possibly slightly saline hydrochemical conditions ( $<100-2,000 \mathrm{mg} / \mathrm{l}$ dissolved solids), probably under the influence of seasonal moisture stress. Beginning 11,500 years ago, limnological conditions of shallow, dilute water of neutral pH prevailed, indicating reduction of moisture stress. A subsequent transition to diatom assemblages indicative of acidic and dystrophic (brown, nutrient-poor water) conditions about 10,000 years ago parallels the establishment of rain-forest vegetation and essentially modern climatic conditions with excess precipitation over evaporation.

The synchroneity and similar character of the paleolimnological changes at these separate and distinctive sites suggests a regional paleoclimatic cause rather than local environmental effects. Latest Pleistocene climates were apparently more continental and drier than Holocene climates in southwestern Tasmania.

\section{INTRODUCTION}

The study of fossil diatoms from two separate lakes, Eagle Tarn and Lake Vera in the mountains of western Tasmania, gives insight into the character of environmental change in southwestern Tasmania during the late Pleistocene and early
Holocene. The paleolimnological information obtained by diatom analysis can address past interactions between land and water. These interactions are controlled by climate through its influence on soils, vegetation, and the amount, seasonality, and character of water entering lakes and ponds. Consequently, paleolimnological studies yield indirect information about climate. The dynamic environmental changes at the end of the Pleistocene and beginning of the Holocene are of particular interest because they set the stage for the development of modern biological communities in Tasmania and may reflect large-scale changes in atmospheric circulation. Diatoms are an important tool for the analysis and documentation of such environmental changes because they colonize rapidly and adapt quickly to changing conditions. Their stratigraphic record thereby provides an exceptionally detailed paleoenvironmental history that longer-lived and more-resistant terrestrial vegetation may obscure. At the same time, the integration of both types of paleoenvironmental indicators will allow a more complete understanding of past environments of this region.

Diatoms typically respond to water chemistry, particularly the amount of dissolved substances (salinity), alkalinity, $\mathrm{pH}$, and certain essential nutrients: silica, phosphorus, and nitrogen (see Cholnoky, 1968, and Bradbury, 1975 for additional references). The interaction of light, nutrients, water depth, turbulence, and other physical characteristics determines the kind of habitats available for diatom growth. For example, shallow lakes in which light reaches the bottom will support benthic diatom communities; deeper, turbulent lakes with seasonally adequate nutrient supplies will support planktonic diatoms. Both the relative and absolute abundance of diatoms will depend on a complex of interacting factors that are generally site specific, but often have an underlying regional-environmental (vegetation, geology, drainage area, etc.), or climatic basis.

\section{LOCATION AND DESCRIPTION OF SITES}

The mountainous region of western Tasmania (Fig. 1) encompasses a diverse geologic terrane of igneous, sedimentary,

$08853-1351 / 86 / 0000-0381 / \$ 03.00$ 


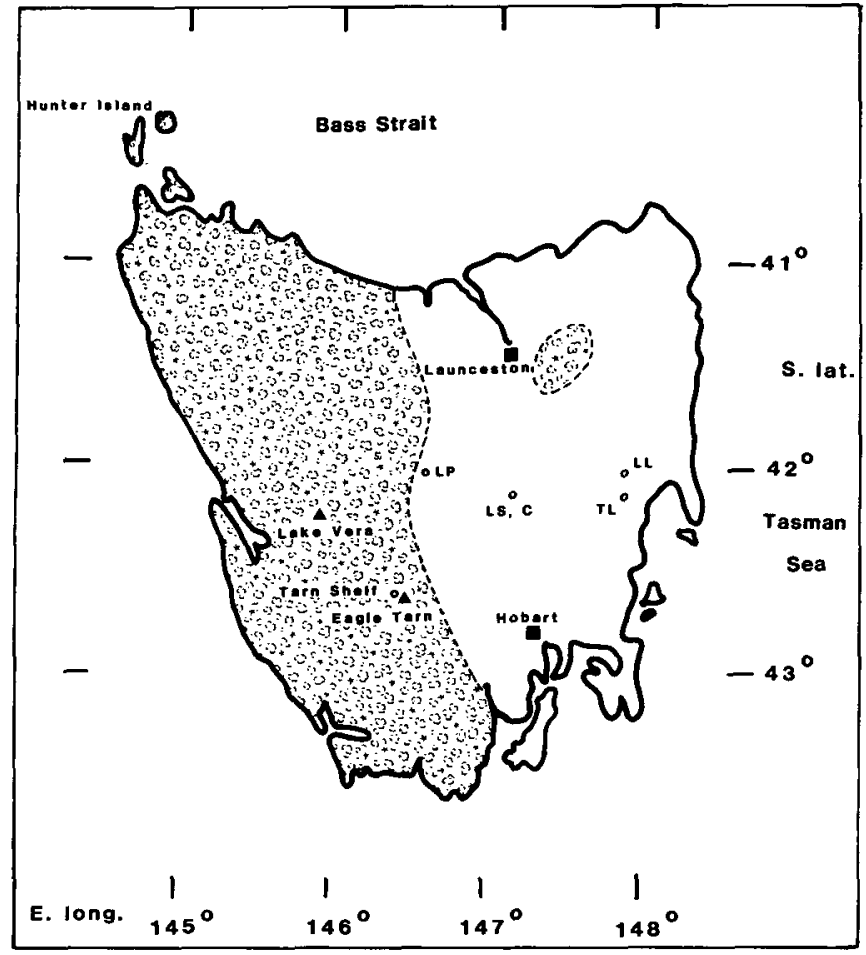

FIGURE 1-index map showing core sites (solid triangles) and investigated lakes in Tasmania. Vegetation design indicates area where precipitation is in excess of evaporation and schematically demarks areas of rain-forest vegetation (Markgraf et al., 1986). Tarn Shelf and Eagle Tarn are located on Mt. Field. $\mathrm{LL}=$ Lake Leake, TL $=$ Tooms Lake, LS,C = Lakes Sorell and Crescent, LP = Little Pine Lagoon.

and metamorphic rocks, and a varied, cool-temperate, rainforest vegetation. Late Wisconsin glaciation is responsible for many landforms and most lakes above $600 \mathrm{~m}$ elevation in the southwest and west, and above $1,000 \mathrm{~m}$ in the eastern part of this region (Macphail, 1979). Modern mean annual precipitation follows a west-to-east gradient $(3,500 \mathrm{~mm}$ to $500 \mathrm{~mm})$ that reflects westerly winds and moisture sources. Within this region moisture stress is mitigated in part by cooler temperatures at higher elevations and latitudes, so that areas above $800 \mathrm{~m}$ with at least $1,200 \mathrm{~mm}$ annual precipitation have a moisture surplus.

Lake Vera, the northernmost and westernmost site in this region $\left(42^{\circ} 16^{\prime} \mathrm{S}\right.$., $145^{\circ} 52^{\prime} \mathrm{E}$.), occurs at an elevation of 550 $\mathrm{m}$, in a terrane of Precambrian metasediments, $4 \mathrm{~km}$ east of Frenchman's Cap, the highest mountain locally $(1,443 \mathrm{~m})$. The basin lies in a steep-sided glacial trough (Macphail, 1979) and is presumably closed by a recessional moraine and glacialoutwash deposits. The lake drains via Vera Creek to the east and is fed by two small creeks that originate in cirques westsouthwest of, and $200 \mathrm{~m}$ above, the lake. The locality receives about $2,800 \mathrm{~mm}$ of mean annual precipitation, has a mean annual temperature of $8.7^{\circ} \mathrm{C}$, and is surrounded by subalpine vegetation (Macphail, 1979; Markgraf et al., 1986).

Lake Vera has an approximate area of 35 ha. Water analyses
(Buckney and Tyler, 1973; Table 1) show it to be a very dilute lake. It is fed largely by snow melt and rain that flows only short distances (about $1 \mathrm{~km}$ ) over and through Precambrian metaquartzites, phyllites, and dolomitic schists covered sparsely by shallow, acidic, infertile soils (Tasmania National Parks and Wildlife Service, 1976). Hydrosere vegetation composed principally of Restio, a sedge-like monocot, forms a mat at the north end of Lake Vera (Macphail, 1979). This wet-sedge mat supports a number of acidophilous benthic diatoms of the genera Eunotia, Frustulia, and Brachysira.

Eagle Tarn $\left(42^{\circ} 40^{\prime}\right.$ S., $146^{\circ} 30^{\prime}$ E.) lies about $62 \mathrm{~km}$ to the east and $44 \mathrm{~km}$ to the south of Lake Vera (Fig. 1) on Mount Field, an isolated plateau of Jurassic dolerites and Mesozoic sedimentary rocks that reaches a maximum elevation of $1,434 \mathrm{~m}$. Eagle Tarn is a small (1.3 ha), moraine-dammed pond at an elevation of $1,033 \mathrm{~m}$. Eagle Tarn and its somewhat larger companion, Lake Dobson, both appear to be impounded by lateral-morainic material from tributary glaciers that flowed north during late Wisconsin time (Tasmania National Parks and Wildlife Service, 1980; Macphail, 1979 and references therein). Eagle Tarn drains to Lake Dobson through a small outlet stream, although substantial amounts of ground water probably seep through the moraine as well.

Mt. Field is at the easternmost limit of Pleistocene glaciation, and at a drier point of the current precipitation gradient $(1,500 \mathrm{~mm}$ mean annual precipitation) in the mountainous region of western Tasmania. Nevertheless, a cooler mean annual temperature $\left(5-6^{\circ} \mathrm{C}\right)$ increases the effectiveness of precipitation, allowing a subalpine, mixed, rain-forest/Eucalyptus woodland to exist. Precipitation occurs throughout the year, but with a winter maximum that frequently includes significant snowfall.

Eagle Tarn has a maximum depth of about $1.5 \mathrm{~m}$, judging from water-level marks on the rock margins of the basin. During seasons of reduced precipitation, the water level falls to about $30-50 \mathrm{~cm}$ above the bottom. The sediment surface consists of an actively growing, algal-rich flocculent mat, populated principally by benthic diatoms, especially species of Brachysira, Achnanthes, Frustulia, and Cymbella. Rooted, aquatic, emergent and submergent vegetation (Eleocharis?, Potamogeton, and Isoetes) grows around the margin of the basin, where mineral sediment closely underlies the gyttja.

About $170 \mathrm{~m}$ above Eagle Tarn and Lake Dobson lies a dolerite ledge, Tarn Shelf, which contains several small, glacially scoured basins with ponds surrounded by alpine-shrub vegetation. These very dilute $(<50 \mathrm{mg} / \mathrm{l}$ total dissolved solids) ponds and pools (Robert Tarn and Mackenzie Tarn, Table 1) contain water that is chiefly derived from snow melt flowing minimal distances over very sparse, undeveloped soils, and unweathered dolerite. Because the ponds on Tarn Shelf are in a treeless area of alpine vegetation and comparatively near the source of water that also fills Eagle Tarn and Lake Dobson, they can be hydrochemically contrasted to these lakes in the mixed subalpine woodland at lower elevations. Although still dilute, Eagle Tarn and Lake Dobson contain more than twice the concentrations of dissolved ions (Table 1), possibly reflecting rock-weathering processes along a somewhat longer ground-water flow path through glacial till to the lower basins. 
TABLE 1-Major dissolved ions in selected Tasmanian lakes $(\mathrm{mg} / 1)$. Conductivity values in micromhos $/ \mathrm{cm}$.

\begin{tabular}{lcccccccccccc}
\hline & $\mathrm{Ca}$ & $\mathrm{Mg}$ & $\mathrm{Na}$ & $\mathrm{K}$ & $\mathrm{HCO}_{3}$ & $\mathrm{CO}_{3}$ & $\mathrm{SO}_{4}$ & $\mathrm{Cl}$ & $\mathrm{Si}$ & Cond. & $\mathrm{TDS}$ & $\mathrm{pH}$ \\
\hline Robert Tarn & 1.3 & 0.61 & 2.5 & .08 & 9 & 0 & $<1$ & 3.5 & 3 & 21.5 & 21 & 6.60 \\
Mackenzie Tarn & 1.6 & 0.35 & 2.2 & .08 & 10 & 0 & $<1$ & 2.5 & 2 & 21.3 & 21 & 6.61 \\
Eagle Tarn & 4.2 & 1.50 & 3.6 & .09 & 15 & 0 & $<1$ & 12.0 & 5 & 40.0 & 45 & 6.55 \\
Lake Dobson & 5.3 & 1.40 & 3.6 & .10 & 22 & 0 & $<1$ & 5.5 & 8 & 36.0 & 49 & 6.68 \\
Lake Vera* & 1.7 & 1.20 & 2.8 & .51 & 6 & 0 & 0.5 & 5.3 & 0.2 & 28.8 & 38.4 & 7.00 \\
Little Pine Lag. & 3.5 & 0.56 & 3.4 & .09 & 15 & 0 & $<1$ & 5.5 & 1 & 38.0 & 31 & 7.15 \\
Lake Leake & 4.6 & 1.10 & 7.8 & .20 & 15 & 0 & $<1$ & 14.0 & 8 & 44.5 & 53 & 6.83 \\
Lake Sorell & 6.7 & 2.20 & 11.0 & .78 & 26 & 0 & 3 & 19.0 & 3 & 72.0 & 74 & 7.72 \\
\hline
\end{tabular}

*Data from Buckney and Tyler (1973).

\section{METHODS AND MATERIALS}

Diatoms were extracted from sediment samples of cores collected from each lake by Macphail (1979), at levels appropriate to encompass the Pleistocene-Holocene transition. Extraction was by acetolysis treatment until all organic matter had been destroyed. The residue, consisting largely of diatoms and variable amounts of silt and clay, was suspended in water and sedimented evenly on cover slips that were mounted in a refractive mounting medium $(n=1.65)$. Between 400 and 700 diatom valves were identified and enumerated from each level, and the relative frequency of major taxa was plotted (Figs. 2 and 3).

\section{Eagle Tarn}

Macphail's (1979) core from Eagle Tarn came approximately from the center of the basin. It consists of nearly uniform gyttja (sediment consisting mostly of algal remains) and bottomed in silt at a depth of $485 \mathrm{~cm}$. The sediment between $445-465 \mathrm{~cm}$ was radiocarbon dated at $11,400 \pm 235$ years B.P. Other radiocarbon dates on this core (Fig. 2) indicate a sediment accumulation rate of about $0.36 \mathrm{~mm} / \mathrm{yr}(28 \mathrm{yr} / \mathrm{cm})$.

A second core from Eagle Tarn, precisely correlated with the Macphail (1979) core by loss-on-ignition analyses, provides additional dates for this sequence (David G. Green, written comm., 1982). These dates are from smaller stratigraphic intervals but have larger standard errors (Markgraf et al., 1986): Nevertheless, they indicate the same sedimentaccumulation rate for the lower part of the core.

In order to examine the paleolimnological changes from the latest Pleistocene to the early Holocene, 12 intervals between 474 and $371 \mathrm{~cm}(11,900$ to 9,600 yrs. B.P.) of the Macphail core were analyzed for diatoms.

\section{Lake Vera}

Macphail's (1979) core from Lake Vera came from the northern end of the lake, at the lakeward edge of a Restio mat. The basal $15 \mathrm{~cm}$ of the core $(285-300 \mathrm{~cm})$, consists of clayey silt. Generally organic lacustrine deposits occur above $280 \mathrm{~cm}$. At $208 \mathrm{~cm}$, the deposits are again silty and the sediment above $160 \mathrm{~cm}$ contains much plant detritus and grades to a sedge peat with rhizomes at the top of the core (Macphail, 1979). Relevant radiocarbon dates from the core (Fig. 3) provide a chronology for the investigated period of lacustrine sedimentation at Lake Vera and indicate a sedimentation rate of $.14 \mathrm{~mm} / \mathrm{yr}(71 \mathrm{yr} / \mathrm{cm})$. The late Pleistocene-early Holocene history of Lake Vera was documented by diatom analysis of eight levels between 299 and $202 \mathrm{~cm}$.

\section{Previous Diatom Studies}

Comparatively little taxonomic and ecologic work has been published on Tasmanian diatoms. Wood (1961) identified several diatom species from Lake Dobson (presumably the Mount Field locality next to Eagle Tarn; Thomas, 1983), and Hustedt (1955) described a number of new taxa from the same site. The limnological studies of Cheng and Tyler (1973a, b) and Croome and Tyler (1973) on the lower-elevation lakes of central Tasmania (Lakes Leake, Tooms, Sorrell, and Crescent) indicate that, in broad terms, the planktonic diatoms of Tasmania are ecologically similar to their counterparts in the Northern Hemisphere. Consequently, qualified paleolimnological interpretations can be made from Tasmanian fossil diatoms, despite the lack of autecological information for some species. In addition, my collections of modern diatoms from an east-west transect of lakes across central Tasmania also provide information about the distribution and habitat preferences of some taxa.

\section{RESULTS AND INTERPRETATION \\ Eagle Tarn}

Diatoms are fairly common (approximately 10 million valves per cc wet sediment) in the basal sample of the Eagle Tarn core (473-474 cm, Fig. 2). The silt-rich sediment at this level is dominated by Cyclotella stelligera, a cosmopolitan planktonic diatom that tends to characterize oligotrophic to somewhat mesotrophic water. By analogy to other sites in Tasmania where $C$. stelligera is common, such as Lakes Leake and Tooms (Croome and Tyler, 1973), it appears that this diatom requires comparatively extensive, limnetic or open-water conditions, clear water, relatively low nutrient levels, and a neutral to slightly basic pH. Its presence in the Eagle Tarn core indicates that, about 12,000 years ago, the lake was significantly larger and deeper than at present, and less acidic.

Fragilaria species, particularly $F$. pinnata and $F$. adamsii, characterize the Eagle Tarn core at two levels below $470 \mathrm{~cm}$, along with appreciable percentages of Navicula sp. cf. $N$. 


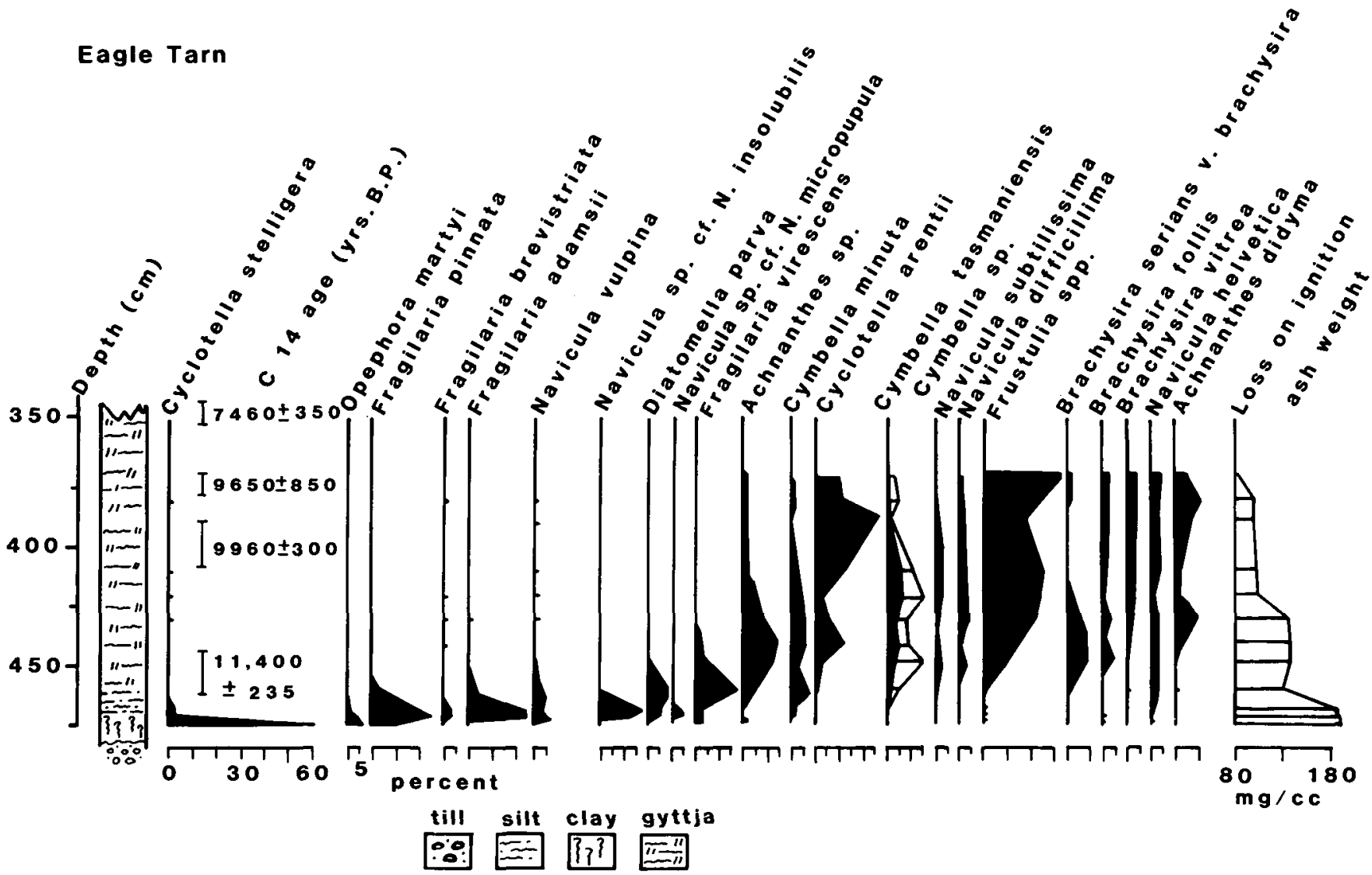

FIGURE 2-Diatom stratigraphy of the basal portion of a core from Eagle Tarn, Mount Field, Tasmania.

insolubilis, N. vulpina, Fragilaria brevistriata, Opephora martyi, Navicula sp. cf. N. micropupula, and Diatomella parva (Fig. 2). The sediments remain comparatively silty at these levels. Collectively, these taxa represent shallow water because they are all benthic or epiphytic species, moving on the bottom or living attached to stems and leaves of submerged aquatic plants. Because they require light for photosynthesis, they are restricted to the photic zone. In small lakes and ponds, benthic Fragilaria species are generally found in depths less than $1 \mathrm{~m}$, although their depth distribution ultimately depends on water clarity and perhaps the influx of nutrients from recharging ground water. A significant increase in the pollen of shallowwater or marsh plants (Cyperaceae and Restionaceae) at a depth of $470 \mathrm{~cm}$ (Macphail, 1979) probably also reflects the lowering of lake level.

Both the dominant and subdominant diatoms in the Eagle Tarn core above $473 \mathrm{~cm}$ (at 471 and $470 \mathrm{~cm}$ ) present a mixed picture of past hydrochemistry about 11,500 years ago. In each sample, some forms, such as Fragilaria adamsii and Navicula sp. cf. N. micropupula (if correctly assigned), clearly belong in oligotrophic, low-pH environments-often typical of cold, mountain tarns and pools (Cholnoky, 1957, 1959, 1964). These acidophilic diatoms are consistently associated with small numbers of Brachysira follis, $B$. serians, and Frustulia sp., which are also found in very dilute, low-pH lakes and ponds. How- ever, the other Fragilaria species, Opephora martyi, Navicula vulpina, and, if correctly assigned, Navicula sp. cf. $N$. insolubilis, co-occur with the acidophilic diatoms and imply generally alkaline and possibly somewhat saline, shallow-water conditions (Cholnoky, 1963, 1968). As with the case for the acidophilous component of diatoms, there exist minor numbers of alkaliphilous diatoms, such as Epithemia adnata, Amphora ovalis, Achnanthes lanceolata, and Caloneis bacillum in association with the dominant alkaliphilic species.

Apparently, Eagle Tarn fluctuated considerably in hydrochemistry over the period of sediment deposition between 473 and $470 \mathrm{~cm}$ and the mixed, benthic diatom assemblage probably represents seasonal changes in water chemistry. A seasonal or short-term moisture stress causing the evaporation and chemical concentration of the tarn could explain the presence of significant numbers of alkaliphilic diatoms. In a similar manner, a seasonal input of fresh water, such as snow melt or a seasonal precipitation maximum, could flush out the shallow basin and fill it with water of low conductivity and low $\mathrm{pH}$ that would support the oligotrophic, acidophilous diatom flora until the dry season returned. The rapid colonization and expansion rates of diatoms, plus their ability to survive unfavorable periods as resting stages, allow each group to take advantage of favorable conditions quickly and account for their co-occurrence in this zone. 


\section{LAKE VERA}

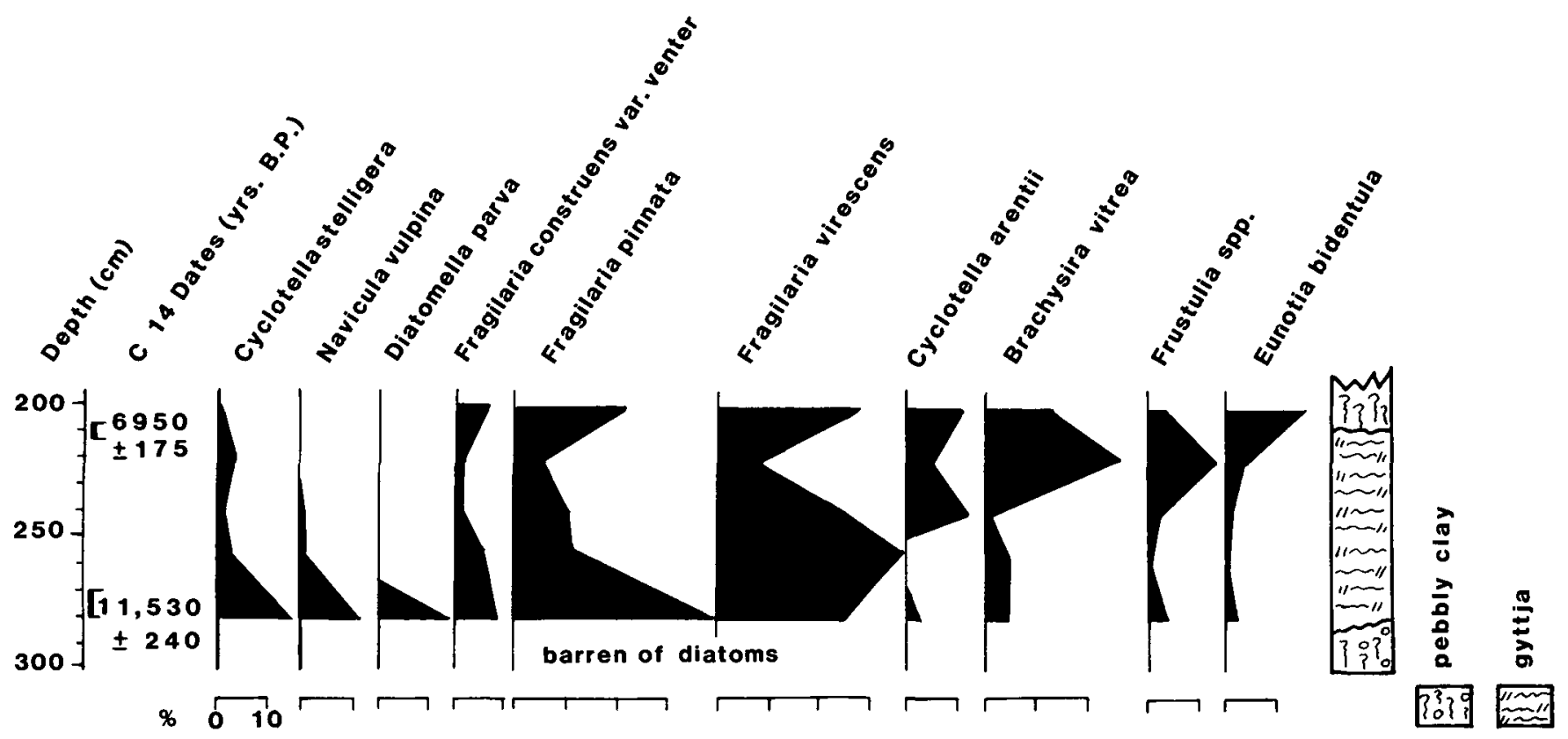

FIGURE 3-Diatom stratigraphy of the basal portion of a core from Lake Vera, Frenchman's Cap, Tasmania.

Diatomella parva and Fragilaria virescens characterize the next-higher sample of the Eagle Tarn core $(463 \mathrm{~cm})$. In addition to these species, Cymbella minuta and a new, gibbous species of Achnanthes (C.W. Reimer, personal comm.) are common. Fragilaria pinnata, F. adamsii, and Navicula vulpina persist at this level but at somewhat lower percentages. As in the previous zone, the diatoms are benthic and indicate comparatively shallow water. The Achnanthes sp. in the core has not been identified, but it is commonly found in Eagle Tarn today, on hard substrates such as submerged wood. It is especially common in the ponds on Tarn Shelf, attached to rocks in shallow water. Also like the diatom assemblages of the previous zone, the diatoms at $463 \mathrm{~cm}$ indicate a mixture of distinct hydrochemical environments, perhaps suggesting some seasonality of precipitation and evaporation. Nevertheless, according to their modern distribution in eastern Australia and New Zealand, the new dominant diatoms in the assemblage, Fragilaria virescens, Cymbella minuta, and Diatomella parva, imply a shift to a predominance of fresher, less-alkaline water, and generally neutral $\mathrm{pH}$ values (Foged, 1978, 1979).

According to loss-on-ignition analyses (Fig. 2), the sediments at this and stratigraphically higher levels are less silty and more organic than sediments below $461 \mathrm{~cm}$. This fact apparently reflects a relative reduction of clastic influx to Eagle Tarn, possibly because terrestrial vegetation had become more thoroughly established in the pond's drainage area.

Above $461 \mathrm{~cm}$, Fragilaria virescens declines, and the following species increase in abundance and characterize the remain- der of the analyzed core (with some fluctuations): Achnanthes sp.; two Cymbella species, cf. $C$. radiosa and $C$. delicatula; Brachysira serians var. brachysira and other Brachysira species; and especially Frustulia rhomboides and Cyclotella arentii. These species are all part of the modern diatom community of Eagle Tarn. For the most part they are present in significant percentages in a surface sample of gyttja from the center of the tarn pool, and most of them can be found to a greater or lesser degree in the sediments of the ponds on Tarn Shelf. This distribution indicates that the limnology of Eagle Tarn had become very similar to its modern condition by the time represented by the $448-\mathrm{cm}$ level in the core (sometime between 11,000 and 11,500 years ago, as dated radiometrically).

The variable percentages of the dominant diatom species above $448 \mathrm{~cm}$ indicate that the limnology of Eagle Tarn was not entirely stable during the early Holocene, but probably fluctuated somewhat in depth, alkalinity, $\mathrm{pH}$, and nutrient status. The most dramatic of these fluctuations is represented by a significant increase in Cyclotella arentii between about 10,200 and 9,500 years ago $(422-382 \mathrm{~cm})$. Today this diatom is rare in Eagle Tarn, although in Mackenzie Tarn, on Tarn Shelf, it appears to be a regular, if still comparatively rare, member of the diatom community. Cyclotella arentii is an acidophilous diatom that can be common in nutrient-poor, dystrophic lakes (Foged, 1972). Its increase in the Eagle Tarn core presumably indicates that the pond became even more acidic and less productive between 10,200 and 9,500 years ago than it was before that time, or is today. The increase in Cyclotella arentii 
correlates with a shift to even more organic-rich sediments, as measured by loss-on-ignition analysis. Eagle Tarn may then have been surrounded by a nutrient-poor, dystrophic fen that prevented mineral sediment from entering the basin. Possibly, the watershed of the site was so completely and densely vegetated that the erosive capacity of surface water entering the lake was greatly reduced.

Paleolimnological fluctuations of this nature are the norm for small-lake systems, and are recorded by diatoms that faithfully respond to the most minor variations in lake chemistry and depth. Cyclotella arentii increases during the period when the pollen record (Macphail, 1979) indicates a dramatic increase in rain-forest vegetation in the area, suggesting that colonization of the Eagle Tarn watershed by subalpine vegetation may have been responsible for the relative reduction of clastic input and the trend toward dystrophic conditions.

Subsequent paleolimnological changes at Eagle Tarn have not been documented by diatom analysis, but data from losson-ignition experiments (D. Green, written comm.) indicate an increased silt content in the core between 180 and $210 \mathrm{~cm}$. This may reflect mid-Holocene environmental changes that increased erosion. Preliminary observation of diatoms above 371 $\mathrm{cm}$ suggests that, throughout the Holocene history of Eagle Tarn, periods of increased dystrophy have alternated with periods characterized by limnological conditions similar to those found in the Tarn today.

\section{Lake Vera}

The diatom stratigraphy of the Lake Vera core (Fig. 3) spans a greater period of time $(3,500$ years) than that of the Eagle Tarn core (2,350 years), but yielded only five productive samples; consequently, its paleolimnological record must be less detailed. The basal sample of the Lake Vera core $(299 \mathrm{~cm})$ is barren, and diatoms are exceedingly rare in the two subsequent samples $(295$ and $290 \mathrm{~cm}$ ). The scattered frustules of Fragilaria virescens, Frustulia rhomboides, and Navicula vulpina at these levels may have been derived from small aquatic environments nearby, or they may represent the initial ponding stages of the lake. If the silt-rich sediment at these levels represents a lacustrine environment at all, a logical analog might be an unproductive, turbid, proglacial melt-water lake (e.g., Whiteside et al., 1980).

The first diatom-rich sample analyzed from the Lake Vera core $(281 \mathrm{~cm})$ lies just below the interval dated at $11,530 \pm 240$ years B.P. This sample is dominated by Fragilaria pinnata and $F$. virescens, with significant percentages of Cyclotella stelligera, Navicula vulpina, Diatomella parva, and $F$. construens var. venter. Smaller numbers of Cyclotella arentii, Brachysira vitrea, Frustulia rhomboides, and Eunotia bidentula are also present. As in Eagle Tarn, this assemblage indicates a predominance of somewhat alkaline, shallow-water conditions. The modest but significant percentages of Cyclotella stelligera may record the waning phase of a deeper and more extensive lacustrine system, but unfortunately, samples between 281 and $290 \mathrm{~cm}$ that might record this phase were unavailable for analysis and this possibility must be speculative. The comparatively large percentages of $F$ ragilaria virescens, together with Brachysira vitrea and the acidophilic species of Cyclotella,
Frustulia, and Eunotia, indicate episodes of lower alkalinity and $\mathrm{pH}$.

The subsequent sample $(255 \mathrm{~cm})$ shows a strong decrease in percentages of alkaliphilic taxa and a corresponding increase in numbers of $F$. virescens, suggesting a predominance of circumneutral-pH water with low conductivity. The percentage distribution of acidophilous diatoms remains essentially unchanged.

By a core depth of $240 \mathrm{~cm}$ (about 9,000 years ago), percentages of acidophilic taxa, particularly Frustulia rhomboides and Cyclotella arentii, have increased significantly, while percentages of $F$. virescens have declined. The number of Brachysira vitrea, a species that is tolerant of low-to-neutral $\mathrm{pH}$ values, also increases dramatically. This trend in the core continues until $220 \mathrm{~cm}$ but is reversed at $202 \mathrm{~cm}$ (perhaps about 6,500 years ago), where alkaliphilous $F$. pinnata and $F$. construens var. venter, and circumneutral $F$. virescens increase. The percentage increase of Eunotia bidentula, an acidophilic taxon (Charles, 1985), suggests some mixing of habitats at this level. The reappearance of large numbers of alkaliphilous diatoms at $202 \mathrm{~cm}$ correlates with a sediment change to a zone of bluish grey clay between 160 and $208 \mathrm{~cm}$ (Macphail, 1979). Presumably, these biotic and sedimentologic changes reflect a shallowing of the lake with the extension of littoral environments into the lake. As Lake Vera became shallower it also became somewhat more alkaline, at least seasonally, presumably because of renewed moisture stress and reduced surface- and ground-water inflow.

The top centimeter of the Lake Vera core represents a sedge-mat environment, where diatoms are comparatively rare and often broken. Nevertheless, the assemblage at the surface is dominated by acidophilic diatoms, particularly Eunotia bidentula, $E$. veneris, $E$. flexuosa, and occasional species of Brachysira. The assemblage indicates that Lake Vera returned to more or less oligotrophic, low-pH conditions, even as the sedge mat grew out into the lake and replaced the earlier shallow-water diatom communities.

\section{DISCUSSION}

The Pleistocene/Holocene transition $(12,000$ to 10,000 years B.P.) was a time of particularly dramatic environmental change in Tasmania (Macphail, 1979; Markgraf et al., 1986). The tarns in this study became lakes only after glacial ice had departed from the area. The earliest stages of lake development are difficult to decipher, because of their sparse biological records and the overwhelming influence of unstable environments of deglaciation (e.g., Bradbury and Whiteside, 1980). However, once the lakes were established, Lake Vera and Eagle Tarn shared a similar developmental pattern. The diatom stratigraphies of the two basins are surprisingly alike. The majority of species in the fossil assemblages are the same, and at both localities the stratigraphy suggests a transition from lakes that were larger and somewhat deeper than at present, with a dominance of Cyclotella stelligera, to shallow, moderately alkaline aquatic environments that became progressively fresher, less alkaline, and more acidic through time. The suggestion of a large, Cyclotella stelligera lacustrine system at Lake Vera 
must remain tentative, because core material at depths between 281 and $290 \mathrm{~cm}$ was not available for study.

Not only is the general paleolimnological trend in both lakes similar, the changes appear to be roughly synchronous, within the reliability of the radiocarbon dates. The Cyclotella stelligera phase at Eagle Tarn, and presumably also at Lake Vera, ended by 12,000 years ago. The moderately alkaline, shallow-water phase in both sites was replaced by acidic and oligotrophic aquatic environments about 11,500 years ago. Rather dystrophic, acidic environments, as indicated by high percentages of Cyclotella arentii, appeared at Eagle Tarn around 9,700 years ago. Sedimentation rates at Lake Vera are too low, and sample intervals too wide, to sufficiently resolve such detail, but the first peak of $C$. arentii at $240 \mathrm{~cm}$ may correlate with this zone at Eagle Tarn.

The dramatic limnological changes, indicated by sediment character and diatom assemblages, that began about 7,000 years ago at Lake Vera have not yet been studied at Eagle Tarn. Preliminary examination of the Eagle Tarn core above $372 \mathrm{~cm}$ indicates that extreme dystrophic conditions returned to the tarn by about 7,500 years ago $(350 \mathrm{~cm})$. Measurements of magnetic susceptibility and loss-on-ignition ash weights (D. G. Green, written comm.) indicate an increased clastic input to Eagle Tarn above $350 \mathrm{~cm}$, perhaps related to lowered lake levels synchronous with those at Lake Vera.

The similarity in character and chronology of paleolimnological changes at Eagle Tarn and Lake Vera suggests a regional environmental cause. Climatic change, independently and through its effect on local vegetation, is the most likely candidate. The Cyclotella stelligera lake at Eagle Tarn may have its modern analog in one of the low-elevation, oligotrophic lakes of the Tasmanian Midlands. Cyclotella stelligera is the dominant planktonic diatom and accounts for most of the planktonic algal biomass in Lakes Leake and Tooms (Croome and Tyler, 1973). This diatom is also abundant in lakes on the Tasmanian Central Plateau, such as Lakes Sorell and Crescent (Cheng and Tyler, 1973), and in Little Pine Lagoon (Fig. 1). A late-glacial climate, similar to the modern conditions at Lake Leake, is not necessarily implied by high percentages of $C$. stelligera. However, those climatic factors that relate to the physical and chemical limnology of this lake or the lakes on the Central Plateau were probably operative to a greater or lesser degree at Eagle Tarn and Lake Vera in the latest Pleistocene. For example, seasonality of precipitation and periods of aridity were likely to have been greater on Mt. Field and Frenchman's Cap at that time than today. The idea of seasonally dry climates is supported by high percentages of non-arboreal pollen at Eagle Tarn and Lake Vera during late-glacial times (Macphail, 1979).

It is probable that some of the water that fed Eagle Tarn and perhaps also Lake Vera initially came from the melting of local glaciers. When that source disappeared, the lakes would have become shallower under a climatic regime of summer moisture stress. If that were the case, the late-glacial paleolimnological record of a more extensive, alkaline lake at Eagle Tarn, and possibly also at Lake Vera, does not suggest increased precipitation, but simply local deglaciation under warming temperatures. The shallow, alkaline-water phase of both Eagle Tarn and Lake Vera that began between 12,000 and 11,500 years ago presumably records dry climates at least seasonally. The transition to diatoms prefering shallow, oligotrophic, circumneutral-pH water, and finally to shallow, dystrophic, acidic conditions, apparently relates to a general increase of effective precipitation, which is also documented by the arrival of rainforest vegetation to the sites.

The diatom stratigraphies of Eagle Tarn and Lake Vera show a close correspondence to the pollen stratigraphies of these sites (Macphail, 1979; Markgraf et al., 1986), and the inferred paleolimnological changes can be correlated with the vegetation changes in a general way. Both vegetation and limnology appear to have responded to paleoclimatic changes, particularly in terms of moisture stress, during the latest Pleistocene and early Holocene of Tasmania.

\section{ACKNOWLEDGMENTS}

The author is particularly indebted to the faculty and staff of the Research School of Pacific Studies, Department of Biogeography and Geomorphology, Australian National University for supporting the field and analytical needs of this study. David G. Green was instrumental in organizing the field work in Tasmania and he kindly shared his insights, radiocarbon dates, and geochemical data for the Eagle Tarn stratigraphy. Michael K. Macphail graciously provided samples of his Eagle Tarn and Lake Vera cores for diatom analysis. This study is part of the U.S. Geological Survey Climate Change Program.

\section{REFERENCES}

BRADBURY, J.P., 1975, Diatom stratigraphy and human settlement in Minnesota: Geological Society of America, Special Paper 171, 74 p.

Bradbury, J.P., and Whiteside, M.C., 1980, The paleolimnology of two lakes in the Klutlan Glacier region, Yukon Territory, Canada: Quaternary Research, v. 14, p. 149-168.

BuCKNEY, R.T., and TYleR, P.A., 1973, Chemistry of Tasmanian inland waters: Internationale Revue der gesamten Hydrobiologie, v. 58, p. $64-78$.

CHARLES, D.F., 1985, Relationships between surface sediment diatom assemblages and lakewater characteristics in Adirondack lakes: Ecology, v. 66 , p. $994-1011$

CHENG, D.M.H., and TyLER, P.A., 1973a, The effect of diatom populations on silica concentrations of Lakes Sorell and Crescent, Tasmania, and utilisation of tripton as a source of silica: British Phycological Journal, v. 8, p. 249-256.

ChEnG, D.M.H., and TyleR, P.A., 1973b, Lakes Sorell and Crescent, a Tasmanian paradox: Internationale Revue der gesamten Hydrobiologie, v. 58 , p. $307-343$.

СноцNоку, B.J., 1957, Uber die Diatomeenflora einiger Gewasser in den Magalies-Bergen nahe Rustenburg (Transvaal): Botaniska Notiser, v. 110 , fasc. 3, p. $325-362$.

Cholnoky, B.J., 1959, Neue und seltene Diatomeen aus Afrika IV. Diatomeen aus der Kaap-Provinz: Osterreichischen Botanischen Zeitschrift, v. 106, p. 1-68.

Cholnoky, B.J., 1963, Beitrage zur Kenntnis des marinen Litorals von Sudafrika: Botanica Marina, v. V, fasc. $2 / 3$, p. 38-83.

Cholnoky, B.J., 1964, Die Diatomeenflora einiger Gewasser der Ruwenzori-Gebirge in Zentralafrika: Nova Hedwigia, v. VIII, 1/2, p. 55-101.

СноLnоку, B.J., 1968, Die Okologie der Diatomeen: Lehre, W. Germany, J. Cramer, $699 \mathrm{p}$.

Croome, R.L., and TYLER, P.A., 1973, Plankton populations of Lake Leake and Tooms Lake-oligotrophic Tasmanian lakes: British Phycological Journal, v. 8, p. 239-247.

FoGED, N., 1972, Notes of diatoms V. Cyclotella arentii and Nitzschia plana var. fennica f. ornata: Svensk Botanisk Tidskrift, v. 66, p. 437-441. 
Foged, N., 1978, Diatoms in Eastern Australia: Bibliotheca Phycologia, v. 41, Vaduz, Lichtenstein, J. Cramer, 148 p., 48 plates.

FOGED, N., 1979, Diatoms in New Zealand, the North Island: Bibliotheca Phycologia, v. 47, Vaduz, Lichtenstein, J. Cramer, 130 p., 48 plates.

HustedT, F., 1955, Neue und wenig bekannte Diatomeen. 8: Naturwissenschaftlicher Verein zu Bremen Abhandlungen, v. 34, p. 47-68.

MACPHAIL, M.K., 1979, Vegetation and climates in southern Tasmania since the last glaciation: Quaternary Research, v. 11, p. 306-341.

MARKGRAF, V., BRADBURY, J.P., and BUSBY, J.R., 1986, Paleoclimates in southwestern Tasmania during the last 13,000 years: PALAIOS, v. 1, p. $368-380$.

Tasmania National Parks and Wildlife Service, 1976, Frenchman's Cap National Park, map and notes: Tasmania National Parks and WildlifeService, LandsDepartment, MagnetCourt, SandyBay, Tasmania.
Tasmania National Parks and Wildlife Service, 1980, Mount Field National Park, map and notes: Tasmania National Parks and Wildlife Service, Lands Department, Magnet Court, Sandy Bay, Tasmania.

THomas, D.P., 1983, A limnological survey of the Alligator Rivers region, Northern Territory. I. Diatoms (Bacillariophyceae) of the region: Research Report 3, Supervising Scientist for the Alligator Rivers Region, Australian Government Publishing Service, 139 p.

Whiteside, M.C., Bradbury, J.P., and TARAPChaK, S.J., 1980, Limnology of the Klutlan moraines, Yukon Territory, Canada: Quaternary Research, v. 14, p. 130-148.

Wood, E.J.F., 1961, Studies on Australian and New Zealand diatoms IV descriptions of further sedentary species: Transactions of the Royal Society of New Zealand, v. 88, part 4, p. 669-698.

In the study of ideas, it is necessary to remember that insistence on hard-headed clarity issues from sentimental feeling, as it were a mist, cloaking the perplexities of fact. Insistence on clarity at all costs is based on sheer superstition as to the mode in which human intelligence functions. Our reasonings grasp at straws for premises and float on gossamers for deductions. 